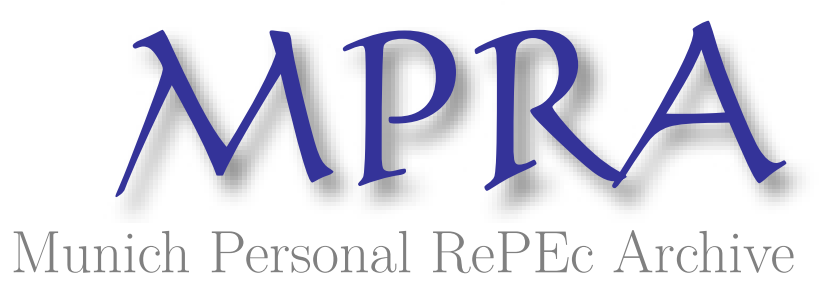

\title{
The risk premium, exchange rate expectations, and the forward exchange rate: Estimates for the Yen-Dollar rate
}

Landon, Stuart and Smith, Constance

University of Alberta, Department of Economics

6 April 1999

Online at https://mpra.ub.uni-muenchen.de/9775/

MPRA Paper No. 9775, posted 31 Jul 2008 05:47 UTC 


\title{
The Risk Premium, Exchange Rate Expectations, and the Forward Exchange Rate: Estimates for the Yen-Dollar Rate*
}

\author{
Stuart Landon and C.E. Smith \\ Department of Economics \\ 8-14 Tory Building \\ University of Alberta \\ Edmonton, Alberta \\ Canada T6G 2H4
}

6 April 1999

Corresponding author:

C. E. Smith

Department of Economics

8-14 Tory Building

University of Alberta

Edmonton, Alberta

Canada T6G 2H4

Phone: $\quad$ (780) $492-5940$

FAX: $\quad$ (780) $492-3300$

e-mail: $\quad$ csmith@econ.ualberta.ca

*We thank an anonymous referee for helpful comments on an earlier draft of this paper. 


\title{
The Risk Premium, Exchange Rate Expectations, and the Forward Exchange Rate: Estimates for the Yen-Dollar Rate
}

\begin{abstract}
The forward rate is often used as the market's prediction of the future spot exchange rate even though the hypothesis that the forward rate is an unbiased predictor of the future spot rate has been rejected in a large number of empirical studies using data for different countries and time periods. The rejection of this hypothesis could occur because market behaviour is inconsistent with rational expectations or because of the existence of a risk premium. Existing studies test for one or the other, but not both, of these factors. In this paper, equations describing the forward premium and the change in the exchange rate are estimated jointly, and tests of both the rational expectations and no risk premium hypotheses are conducted. The empirical estimates, obtained using quarterly data for the yen-dollar exchange rate, reject the rational expectations hypothesis and suggest that there exists a time-varying risk premium.
\end{abstract}

JEL Classification: F31, G14, G11

Keywords: risk premium, forward exchange rate, forward premium 


\section{Introduction}

The assumption of uncovered interest rate parity is widely used in both theoretical and empirical studies. ${ }^{1}$ In conjunction with the covered interest rate parity condition, this assumption implies that the forward exchange rate is equal to the market's prediction of the future spot exchange rate. However, the hypothesis that the forward rate is an unbiased predictor of the future spot rate has been rejected in a large number of studies using data for many different countries and time periods. $^{2}$

Underlying the forward rate unbiasedness hypothesis are the assumptions of no risk premium and rational expectations, where the latter implies that all information useful in predicting the exchange rate is incorporated in the forward premium. The rejection of the unbiasedness hypothesis, as reported in previous studies, indicates that one or both of these assumptions is not consistent with market behaviour. Which of these assumptions does not hold has different implications for the foreign exchange market. The rejection of rational expectations suggests that markets are inefficient while the presence of a time-varying risk premium implies that changes in macroeconomic variables, such as asset supplies, can alter relative asset yields even if expectations are rational.

The aim of the analysis presented in this paper is to determine whether the forward rate unbiasedness hypothesis has been rejected because market behaviour is inconsistent with rational expectations or because there exists a time-varying risk premium. The existing literature on

\footnotetext{
${ }^{1}$ See, for example, Dornbusch (1976), Bilson (1979), Frankel (1979), Driskill (1981), Obstfeld and Rogoff (1984), Meese (1986), Papell (1989), Krugman (1991), Svensson (1992), Goldberg (1994), Mark (1995), and Flood, Garber and Kramer (1996).

${ }^{2}$ See the surveys of Boothe and Longworth (1986), Froot and Thaler (1990), Engel (1995) and Lewis (1995).
} 
unbiasedness has generally examined the rational expectations hypothesis or the hypothesis of a time-varying risk premium, but not both. For example, a large portion of the unbiasedness literature employs empirical tests that are conditional on the assumption that there is no timevarying risk premium. (See Bilson (1981), Longworth (1981), Fama (1984), and the surveys of Boothe and Longworth (1986), Froot and Thaler (1990), Lewis (1995) and Engel (1995).)

Another strand of the unbiasedness literature imposes an exchange rate expectations formation mechanism and then determines whether there exists a risk premium, where the risk premium is calculated as the difference between the forward premium and the forecast change in the exchange rate. Studies that employ survey data to obtain an exchange rate forecast include Froot and Frankel (1989), MacDonald and Torrance (1990), Liu and Maddala (1992), Frankel and Chinn (1993), Cavaglia, Verschoor and Wolff (1994) and Nieuwland, Verschoor and Wolff (1998). Studies that use an estimating equation to derive expectations of the future spot exchange rate include Canova and Ito (1991), Hai, Mark and Wu (1997) and Nessén (1997). ${ }^{3}$ While these studies often find evidence of a time-varying risk premium, they do not attempt to model the risk premium as a function of observed economic variables. As a consequence, they do not provide any information on whether movements in the risk premium are systematic, the reasons for these movements, or the consistency of the calculated risk premium with theoretical models of the risk premium. In addition, these studies cannot test the cross-equation restrictions that implicitly link the exchange rate expectations process and the forward premium equation.

A related group of studies addresses some of these issues by examining whether movements in the risk premium vary systematically with observed economic variables. The

${ }^{3}$ Canova and Ito (1991) use a VAR model and Hai, Mark and Wu (1997) use the Kalman filter to generate an exchange rate forecast. Using data for four European countries, Nessén (1997) combines an estimate of movements of the exchange rate within a target zone with expectations of changes in the target zone itself. 
variables these studies employ include asset stocks (see Frankel (1982), Lewis (1988), Black and Salemi (1988), Engel and Rodrigues (1989), Giovannini and Jorion (1989), Thomas and Wickens (1993) and Engel (1994)), and uncertainty, in the form of changes in the variances of exogenous variables such as government spending, monetary policy or the rate of technological change (see Hodrick (1989), Baillie and Bollerslev (1990), Hu (1997) and Baillie and Osterberg (1997)). In the empirical implementation of these studies, rational exchange rate expectations are imposed and the predicted future exchange rate is set equal to the actual future exchange rate plus a random error. As a consequence, even though these studies have generally not found evidence of a timevarying risk premium, it is uncertain whether this is because there is no risk premium or because the rational expectations assumption is inappropriate.

In contrast to much of the literature, Dominguez and Frankel (1993) attempt to model the risk premium as a function of observed economic variables without imposing rational expectations. To do this, they first generate an estimate of the forward exchange rate risk premium using data on the forward premium and forecasts of exchange rate changes from survey data. Dominguez and Frankel then estimate the impact of central bank intervention on the (generated) risk premium and find that this type of intervention has a significant impact on the risk premium associated with the dollar-mark forward exchange rate. Using survey data, and following a methodology similar to that of Dominguez and Frankel, Giorgianni (1997) also finds evidence in support of a portfolio balance influence (operating through government debt) on the lira-dollar and lira-mark forward exchange rate risk premia.

In this paper, the forward premium is decomposed into two components: a risk premium and the expected change in the exchange rate. The methodology follows Dominguez and Frankel (1993) in that the risk premium is modelled as a function of observed economic variables. To be consistent with theoretical models of asset choice with risk averse investors, the variables assumed 
to affect the risk premium include money supplies, as in Dominguez and Frankel (1993), as well as other potentially important asset stocks such as bonds and equities. Unlike Dominguez and Frankel, the second component of the forward premium, the expected exchange rate change, is generated from a forecasting equation. This type of forecast avoids the problems associated with survey data (see Tagaki (1991)), and allows the cross-equation rational expectations restrictions to be tested. However, because this approach is potentially sensitive to the specification of the forecast equation, several different specifications are used and the robustness of the estimates and tests to changes in the specification are examined.

The approach taken in this paper differs from earlier studies of forward rate unbiasedness in that equations describing the forward premium and the change in the exchange rate are estimated jointly, with the equation describing the change in the exchange rate used to replace the expected exchange rate change variable in the forward premium equation. ${ }^{4}$ The joint estimation of the exchange rate and forward premium equations makes it possible to test the cross-equation restrictions implied by the rational expectations hypothesis as well as to estimate the risk premium and determine whether it is time-varying. ${ }^{5}$ The empirical results obtained, using quarterly data for the Japanese yen-U.S. dollar exchange rate, reject the restrictions associated with the rational expectations hypothesis and confirm that some information useful in predicting the exchange rate is not incorporated in the forward premium. The results also suggest that there exists a timevarying risk premium that explains most of the variation in the forward premium. This risk premium moves systematically in response to changes in asset stocks as predicted by theoretical

\footnotetext{
${ }^{4}$ This methodology is similar to that used by Leiderman (1980) and Mishkin (1983) to test monetary neutrality and rational expectations.

${ }^{5}$ Ayuso and Restoy (1996) also attempt to separate the hypothesis of no risk premium from that of market efficiency, but they employ a different methodology and do not allow for a timevarying risk premium.
} 
models of the risk premium.

The outline of the paper is as follows. The next section presents the theoretical background. Section 3 describes the empirical model and the testing procedures employed. The data and empirical results are described in Section 4. Concluding remarks follow in Section 5.

\section{Theoretical Background}

To determine whether forward rate unbiasedness has been rejected due to the presence of a time-varying risk premium or because market behaviour is inconsistent with rational expectations, it is necessary to employ a model that incorporates a time-varying risk premium. One of the most important models of this type is the extension of the single period capital asset pricing model to an international setting by Solnik (1974). This model has provided a theoretical basis for many empirical studies, including Frankel (1982), Black and Salemi (1988), Lewis (1988), Giovannini and Joiron (1989), Engel and Rodrigues (1989), Thomas and Wickens (1993), Engel (1994) and Glassman and Riddick (1996).

In models of international portfolio choice of the type developed by Solnik (1974), investors choose optimal portfolio shares to maximize expected utility, where the latter is a function of the mean and variance of end-of-period real wealth. The expected return on domestic and foreign currency bonds differs by a risk premium as a result of investor risk aversion. Thus, the risk premium, $\rho$, can be defined as:

$$
\rho_{\mathrm{t}} \equiv \mathrm{i}_{\mathrm{t}}^{\mathrm{d}}-\mathrm{i}_{\mathrm{t}}^{\mathrm{f}}-\Delta \mathrm{s}_{\mathrm{t}+1}^{\mathrm{e}}
$$

where the right hand side of equation (1) is the difference between the expected return on domestic and foreign bonds, $\mathrm{i}^{\mathrm{d}}$ and $\mathrm{i}^{\mathrm{f}}$ are the nominal one period returns in local currency on domestic and foreign currency bonds, respectively, $\mathrm{s}$ is the log of the domestic currency price of 
one unit of foreign currency, and $\Delta \mathrm{s}_{\mathrm{t}+1}^{\mathrm{e}} \equiv \mathrm{E}_{\mathrm{t}}\left(\mathrm{s}_{\mathrm{t}+1}\right)-\mathrm{s}_{\mathrm{t}}$ is the one period expected rate of change in the domestic currency price of the foreign currency.

The covered interest rate parity condition implies that the forward premium equals the difference between the returns on domestic and foreign currency bonds:

$$
f_{t}-s_{t}=i_{t}^{d}-i_{t}^{f},
$$

where $\mathrm{f}$ is the $\log$ of the one-period forward exchange rate. ${ }^{6}$ Using equation (1) to substitute for $\left(\mathrm{i}_{\mathrm{t}}^{\mathrm{d}}-\mathrm{i}_{\mathrm{t}}^{\mathrm{f}}\right)$ in equation (2) yields an equation that describes the forward premium as the sum of two components - the expected change in the exchange rate, $\Delta \mathrm{s}_{\mathrm{t}+1}^{\mathrm{e}}$, and the risk premium, $\rho_{\mathrm{t}}$ :

$$
\mathrm{f}_{\mathrm{t}}-\mathrm{s}_{\mathrm{t}}=\Delta \mathrm{s}_{\mathrm{t}+1}^{\mathrm{e}}+\rho_{\mathrm{t}}
$$

Because the two variables on the right hand side of equation (3) are not directly observable, it is necessary to identify factors that determine $\Delta \mathrm{s}_{\mathrm{t}+1}^{\mathrm{e}}$ and $\rho_{\mathrm{t}}$ before testing for rational expectations and the presence of a risk premium.

Potential determinants of the risk premium, $\rho_{t}$, can be identified using the model of international portfolio choice outlined by Glassman and Riddick (1996). This model is quite general as it allows for both deviations from purchasing power parity and differences in asset preferences across countries. As shown in Appendix I, a model of this type predicts that the risk premium will vary with the supplies of all assets (the world market portfolio) and with the wealth of all countries. As a consequence, the time-varying risk premium can be expressed as:

${ }^{6}$ The covered interest rate parity condition, equation (2), arises because, if there are no arbitrage opportunities and compounding is continuous, the return from purchasing foreign currency, investing the proceeds in a foreign currency asset, and selling the returns forward, $\exp \left(i_{t}^{f}\right) F_{t} / S_{t}$, must equal the return from investing in the otherwise identical domestic currency asset, $\exp \left(i_{t}^{d}\right)$, where $S_{t}$ and $F_{t}$ are the levels of the spot and forward exchange rates, respectively. 


$$
\rho=\rho\left(\mathbf{x}^{\mathrm{m}}, \mathbf{W}, \mathbf{W}\right)
$$

where $\mathbf{x}^{\mathrm{m}}$ is a vector of the world market portfolio of all assets, $\mathbf{W}$ is a vector of national wealth levels, and $\mathrm{W}$ is total world wealth. ${ }^{7}$

Given equation (4), which describes the factors that determine the risk premium, the forward premium equation, equation (3), can be rewritten as:

$$
f_{t}-s_{t}=\Delta s_{t+1}^{e}+\rho\left(x^{m}, \mathbf{W}, W\right)
$$

The next section describes empirical tests of the restrictions on the parameters of equation (5) that are implied by the rational expectations and no risk premium hypotheses.

\section{Empirical Implementation}

As explained above, the hypothesis of forward exchange rate unbiasedness involves two assumptions: that expectations are rational, in the sense that the forecast of the change in the exchange rate utilizes all information that is useful in forecasting the exchange rate, and that there is no risk premium. To conduct empirical tests of these hypotheses, consider the following linearized version of the forward premium equation, equation (5):

$$
\mathrm{f}_{\mathrm{t}}-\mathrm{s}_{\mathrm{t}}=\alpha+\Delta \mathrm{s}_{\mathrm{t}+1}^{\mathrm{e}}+\gamma^{\prime} \mathbf{Z}_{\mathrm{t}}+\varepsilon_{\mathrm{t}}^{\mathrm{r}}
$$

where $\alpha$ is a constant, $\mathbf{Z}_{\mathrm{t}}$ is a vector of variables that determine the time-varying risk premium, $\boldsymbol{\gamma}$ is a vector of parameters, $\varepsilon_{\mathrm{t}}^{\mathrm{r}}$ is a random error and $\alpha+\boldsymbol{\gamma}^{\prime} \mathbf{Z}_{\mathrm{t}}+\varepsilon_{\mathrm{t}}^{\mathrm{r}}$ is a linearization of $\rho\left(\mathbf{x}^{\mathrm{m}}, \mathbf{W}, \mathbf{W}\right)$.

To estimate equation (6) and test the rational expectations hypothesis, it is necessary to

${ }^{7}$ Under some circumstances (such as if purchasing power parity holds), the optimal portfolio of risky assets is the same for all investors, in which case there are no individual country wealth effects (Glassman and Riddick (1996)). 
specify an equation describing the expected change in the exchange rate, $\Delta \mathrm{s}_{\mathrm{t}+1}^{\mathrm{e}}$. Suppose the actual change in the exchange rate from period $\mathrm{t}$ to period $\mathrm{t}+1$ can be expressed as:

$$
\Delta \mathbf{s}_{\mathrm{t}+1}=\mathbf{b}^{\prime} \mathbf{V}_{\mathrm{t}}+\varepsilon_{\mathrm{t}+1}^{\mathrm{s}},
$$

where $\mathbf{V}_{\mathrm{t}}$ is a vector of variables known at time $t$ that forecast the future value of the exchange rate, $\mathbf{b}$ is a vector of parameters and $\varepsilon_{\mathrm{t}+1}^{\mathrm{s}}$ is a random error with mean zero.

Equations (6) and (7) can be used to derive the implications of the rational expectations and no time-varying risk premium hypotheses. To do so, the expected exchange rate change, $\Delta \mathrm{s}_{\mathrm{t}+1}^{\mathrm{e}}$, is obtained by taking the expectation at time $\mathrm{t}$ of equation (7). This expected exchange rate change is then substituted into the forward rate equation, equation (6), to yield an equation for the forward premium that is a function of observable variables only:

$$
\mathrm{f}_{\mathrm{t}}-\mathrm{s}_{\mathrm{t}}=\alpha+\boldsymbol{\beta}^{\prime} \mathbf{V}_{\mathrm{t}}+\gamma^{\prime} \mathbf{Z}_{\mathrm{t}}+\varepsilon_{\mathrm{t}}^{\mathrm{r}} .
$$

The rational expectations hypothesis implies that the parameter vector $\mathbf{b}$ that enters the exchange rate equation, equation (7), is the same as the parameter vector $\boldsymbol{\beta}$ in the forward premium equation. Hence, rational expectations can be tested by estimating equations (7) and (8) jointly and testing the cross-equation restrictions:

$$
\boldsymbol{\beta}=\mathbf{b} .
$$

If this restriction is rejected, the expected exchange rate that enters the forward premium equation is not consistent with the process determining the exchange rate. Thus, forward market participants will be making systematic expectational errors. As well, rational expectations requires that the expectation error, $\varepsilon_{\mathrm{t}+1}^{\mathrm{s}}$, be orthogonal to all information available in period t. If the cross-equation restriction is not rejected, but this orthogonality condition is violated, market 
behaviour is again not consistent with rational expectations.

The hypothesis of no time-varying risk premium implies that the forward premium is not affected by the variables included in the vector $\mathbf{Z}_{\mathrm{t}}$. In other words, this hypothesis imposes the following restrictions on equation (8):

$$
\gamma=\mathbf{\imath} 0
$$

where $\mathbf{l}$ is a vector of ones. ${ }^{8}$ The hypothesis of no risk premium, either constant or time-varying, imposes the joint restrictions:

$$
\gamma=\mathbf{\imath} 0, \alpha=0
$$

\section{Data and Empirical Results}

\subsection{The Data}

The model of the forward premium described by equations (7) and (8) is estimated using a sample of quarterly data for the U.S. and Japan that begins in 1975Q2, the period in which some of the data is first available, and ends in 1994Q1. ${ }^{9}$ The yen-dollar forward premium and the actual

\footnotetext{
${ }^{8}$ If the rational expectations cross-equation restrictions are imposed $(\mathbf{b}=\boldsymbol{\beta})$, the no risk premium restriction $(\boldsymbol{\gamma}=\mathbf{l} 0)$ can be tested even if the elements of $\mathbf{V}_{t}$ and $\mathbf{Z}_{t}$ are identical. However, if rational expectations is not imposed, the no time-varying risk premium restriction can only be tested for those elements of the vector $\mathbf{Z}_{t}$ that do not appear in the vector $\mathbf{V}_{t}$. Given the final specifications of the exchange rate forecasting equations used in the empirical analysis below, the elements of the vectors $\mathbf{V}_{t}$ and $\mathbf{Z}_{t}$ are non-overlapping and, thus, all the elements of the parameter vectors $\boldsymbol{\beta}$ and $\boldsymbol{\gamma}$ are identified. As a result, the restrictions given in equations (10) and (11) can be tested whether or not rational expectations is imposed.

${ }^{9}$ Details of the data construction and the data sources are provided in Appendix II. Breuer and Wohar (1996) discuss some of the potential institutional problems with using end-of-month forward exchange rate data. While their empirical results provide suggestive evidence that this is a problem for some countries, they do not find a significant problem with data for Japan. Bekaert and Hodrick (1993) find that the exact matching of forward and future spot exchange rates to account for institutional features has a very small effect on parameter estimates.
} 
change in the exchange rate (measured on a quarterly percentage basis) are graphed in Figure 1. As is evident from this figure, there is much greater volatility in the exchange rate than in the forward premium. The standard deviation of the forward premium $\left(\mathrm{f}_{\mathrm{t}}-\mathrm{s}_{\mathrm{t}}\right)$ is .8 percent per quarter, while the standard deviation of the change in the exchange rate $\left(\mathrm{s}_{\mathrm{t}+1}-\mathrm{s}_{\mathrm{t}}\right)$ is 6.1 percent per quarter.

Before the forward premium equation can be estimated, it is necessary to determine the variables that form the elements of the vector $\mathbf{Z}_{\mathrm{t}}$, the vector of variables that enter the linearization of the risk premium equation. In previous studies that attempt to model a risk premium, the asset stocks used to determine the risk premium have included money (Dominguez and Frankel (1993)), government bonds (Frankel (1982), Lewis (1988) and Engel and Rodrigues (1989)), or government bonds and equities (Thomas and Wickens (1993) and Engel (1994)). To allow for a very general model of risk premium determination, the vector $\mathbf{Z}_{\mathrm{t}}$ includes the stocks of U.S. and Japanese money $\left(\mathrm{M}^{\mathrm{us}}, \mathrm{M}^{\mathrm{J}}\right)$, government bonds $\left(\mathrm{B}^{\mathrm{US}}, \mathrm{B}^{\mathrm{J}}\right)$, and equities $\left(\mathrm{A}^{\mathrm{US}}, \mathrm{A}^{\mathrm{J}}\right)$. Due to the growth in the nominal magnitudes of these variables over the sample period, these asset stocks were included in real difference form. The real current account balances of both countries $\left(\mathrm{CA}^{\mathrm{US}} / \mathrm{P}^{\mathrm{US}}\right.$, $\left.\mathrm{CA}^{\mathrm{J}} / \mathrm{P}^{\mathrm{J}}\right)$ are also included in the risk premium equation to reflect the country specific wealth effects that determine the risk premium ( $\mathbf{W}$ in equation (4)).

\subsection{Exchange Rate Forecasts}

Specification

To estimate the forward premium equation, equation (8), it is necessary to choose a specification for the exchange rate forecasting equation, equation (7). To provide an indication of the sensitivity of the parameter estimates and test results to the form of the exchange rate forecasting equation, three different exchange rate forecasting models are employed.

The first, and most general, exchange rate forecasting model used was obtained by 
considering for possible inclusion in the vector $\mathbf{V}_{\mathrm{t}}$ of the forecasting equation (equation (7)) a large number of variables that theoretical and empirical studies suggest may be important determinants of the exchange rate. These variables include the current and lagged changes in the real national incomes of the U.S. $\left(\Delta\left(\mathrm{Y}^{\mathrm{US}} / \mathrm{P}^{\mathrm{US}}\right)\right)$ and Japan $\left(\Delta\left(\mathrm{Y}^{\mathrm{J}} / \mathrm{P}^{\mathrm{J}}\right)\right)$, interest rates on short and long term U.S. dollar and Japanese yen bonds $\left(\mathrm{rs}^{\mathrm{US}}, \mathrm{rl}^{\mathrm{US}}, \mathrm{rs}^{\mathrm{J}}, \mathrm{rl}^{\mathrm{J}}\right)$, lagged values of the forward premium, lagged changes in the exchange rate, as well as the current and lagged values of all the asset stock and wealth variables that are possible determinants of the risk premium (the elements of the vector $\left.\mathbf{Z}_{t}\right) \cdot{ }^{10}$ To provide a parsimonious and efficient forecast, a sequential reduction procedure was employed to eliminate the many variables in the initial specification of the forecasting equation that did not contribute significantly to the forecast. A complete description of the methodology used to determine the final specification of this "general" forecasting equation is given in Part A of Appendix III.

The second specification employed for the exchange rate forecasting model, the "simple" specification, includes only lagged values of the change in the exchange rate as explanatory variables (that is, as elements of the vector $\mathbf{V}_{\mathrm{t}}$ ). This form was motivated by survey studies that find traders in the foreign exchange market often rely on forecasts that are based on past trends in the exchange rate, particularly for short time horizons (Takagi (1991), Taylor and Allen (1992), Lui and Mole (1998)). If forecasts that use structural models are costly, a very simple forecast model such as this may provide an attractive alternative. One shortcoming of this type of forecast is that the forecast prediction error is likely to be correlated with variables that are observable at

\footnotetext{
${ }^{10}$ To ensure that the forecast of the exchange rate uses only data that would have been available at the time of the forecast, the time $t$ value used for all the variables initially included in the forecasting equation is the most recent value of each variable that would have been observable at time t. For data available on a quarterly basis, the observations used are those at the end of the previous quarter (that is, lagged one quarter). For data available on a monthly basis (except for interest rates which are immediately observable), the observations used are those at the end of the previous month.
} 
time t. If this is the case, the forecast will not be rational in the sense of using all available information. Nevertheless, by employing this type of forecast it is possible to examine whether the estimation results are sensitive to the use of very different forecasting equations.

The third exchange rate forecasting model used to estimate the forward premium equation assumes a "random walk" exchange rate forecast in which the current spot exchange rate is the forecast of the future spot rate. The use of a random walk forecast by market participants would imply that the expected change in the exchange rate is zero. (That is, $\Delta \mathrm{s}_{\mathrm{t}+1}^{\mathrm{e}}=\boldsymbol{\beta}^{\prime} \mathbf{V}_{\mathrm{t}}$ is zero in the forward premium equation, equation (8).) With this specification it is unnecessary to estimate a forecasting equation in order to estimate equation (8). One justification for using a random walk forecast is, as noted by Taylor $(1995,14)$, that "time series for the major nominal exchange rates over the recent float are extremely hard to distinguish empirically from random walks." For example, the work of Meese and Rogoff (1983), and the large empirical literature that followed, indicates that most structural models of the exchange rate provide little improvement over a random walk forecast, especially at short horizons. ${ }^{11}$ As with the simple forecast model that incorporates only lagged values of the exchange rate, a random walk forecast is unlikely to satisfy the orthogonality criteria of rational expectations.

\section{Estimates of the Exchange Rate Forecasting Equations}

Estimates of the first two exchange rate forecasting models described above, the "general" and "simple" models, respectively, are presented in Table 1. As the results indicate, the estimates of the parameters of both models are not rejected by a number of diagnostic tests, although the

\footnotetext{
${ }^{11}$ Other studies of exchange rate forecasts include Engel and Hamilton (1990), Chinn and Meese (1995) and Mark (1995). Frankel and Rose (1995) provide a review of the recent empirical literature, and argue that structural models of the exchange rate do not dominate a random walk forecast at short horizons.
} 
general model explains a far greater proportion of the variation in the exchange rate change than does the simple model.

Using the general forecasting model, out-of-sample one quarter ahead forecasts of the exchange rate for the last five years and last ten years of the sample yield forecasts with a lower mean squared error and a lower mean absolute error than a random walk forecast. (See Table A1 in Appendix III. ${ }^{12}$ ) Figures $2 \mathrm{~A}$ and $2 \mathrm{~B}$ graph the actual change in the exchange rate and the change predicted by the general and simple models, respectively. The general forecast model tracks the changes in the exchange rate relatively well in comparison to the simple forecast, and particularly well in comparison to a random walk model which would predict the future change in the exchange rate to always be zero.

\section{$\underline{4.3 \text { Estimates of the Forward Premium Equation }}$}

As discussed in Section 3, it is possible to test the hypotheses of rational expectations and no risk premium by testing restrictions on the parameters of equations (7) and (8), the exchange rate forecasting and forward premium equations, respectively. To do this, it is necessary to jointly estimate the forward premium equation and the exchange rate forecasting equation. Table 2 reports the maximum likelihood estimates of the coefficients of the forward premium equation, the parameter vector $\boldsymbol{\gamma}$ in equation (8), when the cross-equation restrictions implied by the rational expectations assumption are imposed. Estimates are reported for each of the the three exchange rate forecasting models: the general exchange rate forecast, the simple exchange rate forecast, and

\footnotetext{
${ }^{12}$ Note that the general forecast model predicts more accurately than a random walk and a random walk with drift whether the regression is a rolling regression or not. While the forecasts presented in Table A1 of Appendix III are out-of-sample, in the sense that the parameters of the model are estimated using only a sub-sample of the available observations and the forecasts are undertaken for the remaining observations, the structure of the forecasting equation (that is, the variables included in this equation, but not the parameter estimates) was determined using the entire sample.
} 
the random walk forecast. To capture the possibility of slow adjustment in the risk premium, four lags of the risk premium variables were initially included in the forward premium estimating equation. ${ }^{13}$ However, to obtain a more parsimonious specification, a lag reduction procedure as described in Part B of Appendix III was used to reduce the number of lagged variables. ${ }^{14}$ As indicated in Table 2, the estimates explain a large proportion of the variation in the forward premium and the estimates provide no evidence of serial correlation (at the one percent significance level), heteroscedasticity, or structural change. As well, normality of the residuals is not rejected (at the one percent significance level) in two of the three cases. ${ }^{15}$

There are many similarities in the estimated risk premium parameters associated with the three different forecasting equations. This robustness of the estimates of the risk premium parameters to changes in the variables included in the exchange rate forecasting equation suggests that the variables determining the risk premium are not acting as proxies for variables that have been omitted from one of the exchange rate forecasting equations, but included in one of the others.

\subsection{Tests of the Rational Expectations and No Risk Premium Hypotheses}

\subsubsection{Tests of the Rational Expectations Hypothesis}

\footnotetext{
${ }^{13}$ Slow adjustment is consistent with the findings of Eichenbaum and Evans (1995) who observe slow adjustment of the exchange rate and domestic and foreign interest rates following changes in U.S. monetary policy.

${ }^{14}$ Table 2 reports a likelihood ratio test of the exclusion restrictions imposed by the lag length reduction procedures. For all three cases, these exclusion restrictions are not rejected.

${ }^{15}$ The hypothesis that the forward premium is nonstationary (has a unit root) is rejected. With one lag of the change in the forward premium included in the test equation, the test statistic is 3.18 (the finite sample 5 percent critical value is -2.91). The rejection of a unit root is invariant to whether the test equation includes zero or four lagged changes of the forward premium, whether or not the forward premium is deseasonalized, or whether the test utilizes asymptotic or finite-sample critical values.
} 
The rational expectations hypothesis — that all information useful in predicting the exchange rate is incorporated in the forward premium — is tested by testing the cross-equation restrictions given in equation (9). These restrictions imply that the elements of the parameter vector $\mathbf{b}$ in the exchange rate forecasting equation, equation (7), are equal to the elements of the parameter vector $\boldsymbol{\beta}$ in the forward premium equation, equation (8).

The results of the tests of the cross-equation restrictions implied by the rational expectations hypothesis are reported in the first row of Table $3 .{ }^{16}$ The cross-equation restrictions are rejected at the 95 percent confidence level using the general exchange rate forecasting model. This result implies that some information useful in predicting the exchange rate, information included in the general exchange rate forecasting equation, is not incorporated in the forward premium. If market participants had used this information, it would have been reflected in the forward premium and the cross-equation restrictions should not have been rejected.

When the simple exchange rate forecasting model is employed, the results in the first row of Table 3 indicate that the rational expectations cross-equation restrictions are not rejected. This finding is consistent with market participants incorporating a simple exchange rate forecast in the forward premium. However, this forecast does not include several variables that, from the construction of the general exchange rate forecasting specification, are known to be useful predictors of the exchange rate. In this sense, the model that uses the simple exchange rate forecast exhibits market inefficiency since it does not incorporate all available information in the forward premium.

\footnotetext{
${ }^{16}$ This hypothesis is not testable with a random walk forecast since, with this type of forecast, both $\mathbf{b}$ and $\boldsymbol{\beta}$ are effectively set to zero.
} 


\subsubsection{Tests of the No Risk Premium Hypothesis}

Part 2 of Table 3 reports the results of likelihood ratio tests of the hypotheses of no timevarying risk premium (equation (10)) and no constant or time-varying risk premium (equation (11)). Part 2.A of Table 3 reports the results of these tests when the rational expectations crossequation restrictions are imposed. In Part 2.B of Table 3, the results are given for tests of the no risk premium hypotheses when the rational expectations restrictions are not imposed. By reporting both sets of test results it is possible to determine whether, if the no risk premium hypothesis is rejected when the rational expectations cross-equation restrictions are imposed, this rejection occurs because the rational expectations restrictions are inconsistent with the data.

The likelihood ratio test statistics reported in Part 2 of Table 3 indicate that the no risk premium hypothesis is strongly rejected for all three cases whether or not the rational expectations restriction is imposed. ${ }^{17}$ As a check that the significant risk premium variables (the variables in the vector $\mathbf{Z}$ ) are not proxying exchange rate forecasting effects, these variables were added individually into each of the exchange rate forecasting equations. None of the variables that would be observable in the current period were found to be significant determinants of the exchange rate. This implies that the risk premium variables in the forward premium equation are significant because they directly determine the forward premium, not because they contribute to a better forecast of the exchange rate. ${ }^{18}$

The results of the tests in Part 2 of Table 3 suggest that asset stocks and wealth levels have an important influence on the forward premium. These test results are consistent with the many

\footnotetext{
${ }^{17} \mathrm{~A}$ test of the joint hypothesis of rational expectations and no time-varying risk premium is also easily rejected for both forecasting models.

${ }^{18}$ If the lagged forward premium is added as an explanatory variable to the forward premium equation, it is not significant if rational expectations is not imposed. Thus, the risk premium variables are not acting as a proxy for the lagged forward premium.
} 
significant parameter estimates associated with the risk premium variables reported in Table 2 . In particular, the Japanese and U.S. money ${ }^{19}$ and equity ${ }^{20}$ variables and the Japanese and U.S. current account (wealth) variables all have a significant effect on the forward premium. ${ }^{21}$

The evidence presented in Table 3 indicates the presence of a time-varying risk premium that depends on asset stocks and changes in wealth. However, these test results do not indicate the importance of these factors, in terms of the magnitude of their effect, in the determination of the forward premium. To illustrate the importance of the risk premium in the determination of the forward premium, Figures 3A, 3B, and 3C graph the actual forward premium and the estimated risk premium, where the latter is calculated using the parameter estimates $\left(\hat{\alpha}+\hat{\gamma}^{\prime} \mathbf{Z}_{t}\right)$ from Table 2 associated with the general, simple and random walk forecast models. As these figures clearly indicate, the predicted risk premium closely tracks actual changes in the forward premium in both

\footnotetext{
${ }^{19}$ The positive coefficients on the U.S. money supply variables in Table 2 are consistent with the results of Eichenbaum and Evans (1995) who find that in the six months following contractionary U.S. monetary policy there is a fall in the yen-dollar risk premium (given perfect foresight exchange rate expectations). Baillie and Osterberg (1997) also find evidence that money supply variables (central bank foreign exchange market intervention) has an impact on the forward exchange rate risk premium.

${ }^{20}$ Bekaert and Hodrick (1992) observe that dividend yields (one type of equity market variable) affect the excess dollar-yen foreign exchange return $\left(s_{t+1}-f_{t}\right)$. However, the variable they explain differs from the forward premium $\left(\mathrm{f}_{\mathrm{t}}-\mathrm{s}_{\mathrm{t}}\right)$ examined here.

${ }^{21} \mathrm{An}$ increase in wealth leads to a relative increase in demand for home assets if there are violations of purchasing power parity, which lead to "home bias" (see Glassman and Riddick (1996)). Home bias implies that an increase in Japanese wealth (a Japanese current account surplus) leads to an increase in demand for Japanese assets, causing a fall in Japanese bond and other Japanese asset yields relative to the yields on comparable U.S. assets. As a result, the risk premium on the yen is predicted to fall. For similar reasons, an increase in the U.S. current account would be expected to lead to an increase in the risk premium on the yen. In the case of the Japanese current account, the fourth quarter effect is positive and significant, but most of the other quarterly effects are negative and the sum of the quarterly effects is generally negative, as predicted by a model with home bias. In contrast, a U.S. current account surplus reduces the forward premium on the yen-dollar forward rate. Since the U.S. is Japan's largest trading partner, but Japan is not the largest trading partner of the U.S., in the U.S. case, there may be third-country effects of current account changes that are not being captured in this model.
} 
direction and magnitude. In contrast, as shown in Figures $4 \mathrm{~A}$ and $4 \mathrm{~B}$, there is little relationship between the forward premium and the forecast change in the exchange rate using the general and simple exchange rate forecasts $\left(\mathbf{b}^{\prime} \mathbf{V}_{t}\right)$ from Table 1.

The contrast in the relationship between the forward premium and the predicted risk premium, and the forward premium and the forecast exchange rate change, can also be seen by comparing the simple correlation coefficients reported in Table 4. The correlations between the forward premium and the predicted risk premium using the three exchange rate forecasting models are quite high, ranging from .782 for the general forecasting model to .887 for the random walk model. In contrast, the correlation between the forward premium and the forecast exchange rate change is negative for both the predictions of the general and simple exchange rate forecasting models.

\section{Concluding Comments}

The findings of this paper provide evidence that may help to explain the consistent empirical rejection of the hypothesis of forward exchange rate unbiasedness. The results show, in the case of the yen-dollar exchange rate, that the rejection of this hypothesis can be attributed to both forward exchange market inefficiency (expectations are not rational) and a time-varying risk premium.

The estimation methodology employed in this paper makes it possible to estimate the independent effects of a risk premium and exchange rate expectations on the forward premium. This allows for a direct test of rational expectations (market efficiency). If market participants have rational expectations, then information useful in predicting the exchange rate should be incorporated in the forward premium. The cross-equation restrictions associated with the rational expectations hypothesis are not rejected using a simple exchange rate forecast 
based on lagged values of the exchange rate. However, with a more general forecast model that allows a large number of observable economic variables to enter the information sets of market participants, the cross-equation restrictions are rejected.

The rejection of the rational expectations cross-equation restrictions for the model that employs the general exchange rate forecast suggests that information useful in predicting the exchange rate is not being incorporated in the forward premium. While the cross-equation restrictions are not rejected for the simple forecast model, this model does not include several variables that are known to be useful in predicting the exchange rate. Thus, the results for both forecast models suggest there is some inefficiency in the forward exchange market. A possible explanation for this inefficiency, which deserves further study, is that it may be too costly to produce an exchange rate forecast that is significantly superior to a simple or random walk forecast. MacDonald and Taylor (1992), in their review of the forward market efficiency literature, note that there is a potential for future research that integrates exchange rate forecasts based on past trends with forecasts based on more fundamental factors.

The empirical results reported above reject the hypothesis of no time-varying forward exchange rate risk premium for three different specifications of the exchange rate forecasting equation, with and without rational expectations imposed. The time-varying risk premium found here is shown to vary with changes in asset supplies and wealth, as predicted by theories of international portfolio allocation with risk averse assetholders. These results are not sensitive to the form of the exchange rate forecasting equation.

Finally, the results reveal a close and robust relationship between the risk premium and the forward premium. This, plus the finding that the forecast of the change in the exchange rate bears little relationship to the forward premium, suggests that most of the variation in the dollar-yen forward premium results from changes in the risk premium rather than from changes in the expected exchange rate. 


\section{Table 1}

\section{Estimates of the Exchange Rate Forecast Equation}

\section{General Forecast Model Simple Forecast Model}

\begin{tabular}{|c|c|c|}
\hline$\Delta\left(\mathbf{M}^{\mathrm{US}} / \mathbf{P}^{\mathrm{US}}\right)^{\mathrm{O}}$ & $\begin{array}{l}.4018^{*} \\
(2.32)\end{array}$ & \\
\hline$\Delta\left(\mathbf{M}^{\mathrm{US}} / \mathbf{P}^{\mathrm{US}}\right)_{-3}^{\mathrm{O}}$ & $\begin{array}{l}-.5381 * \\
(3.34)\end{array}$ & \\
\hline$\Delta \mathbf{r s}_{-3}^{\mathrm{US}}$ & $\begin{array}{l}-.0140 * \\
(3.37)\end{array}$ & \\
\hline$\Delta r \mathbf{l}_{-3}^{\mathrm{US}}$ & $\begin{array}{l}.0455^{*} \\
(5.13)\end{array}$ & \\
\hline$\Delta \mathbf{r l}_{-2}^{\mathrm{J}}$ & $\begin{array}{l}.0278 * \\
(3.06)\end{array}$ & \\
\hline$f_{-1}-S_{-1}$ & $\begin{array}{l}-1.335^{*} \\
(2.01)\end{array}$ & \\
\hline$\Delta \mathbf{s}$ & & $\begin{array}{l}.1465 \\
(1.26)\end{array}$ \\
\hline$\Delta \mathbf{s}_{-1}$ & & $\begin{array}{l}-.0539 \\
(.46)\end{array}$ \\
\hline$\Delta \mathbf{s}_{-2}$ & & $\begin{array}{l}.0896 \\
(.76)\end{array}$ \\
\hline$\Delta \mathbf{s}_{-3}$ & & $\begin{array}{l}.1433 \\
(1.21)\end{array}$ \\
\hline$\Delta \mathbf{s}_{-4}$ & $\begin{array}{l}-.3024 * \\
(3.10)\end{array}$ & $\begin{array}{l}-.2470 * \\
(2.09)\end{array}$ \\
\hline Constant & $\begin{array}{l}-.0241 * \\
(3.25)\end{array}$ & $\begin{array}{l}-.0128 \\
(1.71)\end{array}$ \\
\hline $\mathrm{R}^{2}$ & .4675 & .0991 \\
\hline $\mathrm{R}^{2}$ & .4127 & .0347 \\
\hline $\operatorname{AR}(1)\left(\chi^{2}(1)\right)$ & .06 & .92 \\
\hline
\end{tabular}


$\operatorname{AR}(4)\left(\chi^{2}(1)\right)$

$\operatorname{AR}(1,2,3,4)\left(\chi^{2}(4)\right)$

Reset Test (t-statistic)

Breusch-Pagan-Godfrey test

for heteroscedasticity $\left(\chi^{2}\right.$-statistic)

ARCH heteroscedasticity test

$\left(\chi^{2}(1)\right.$-statistic)

Structural Shift Dummy (t-statistic) $\quad .82$
.01

1.08

1.11

1.12

.23

1.39

\section{Notes:}

*Indicates the parameter is significantly different from zero at the $95 \%$ confidence level.

The number in brackets below a test statistic is the number of degrees of freedom for the test.

For variable $\mathrm{x}_{\mathrm{t}}, \Delta \mathrm{x}_{\mathrm{t}}=\mathrm{x}_{\mathrm{t}}-\mathrm{x}_{\mathrm{t}-1}$.

Estimation Period: 1975Q2 - 1994Q1.

The superscript "O" on the money stock variables indicates that this is the most recent data that would have been observable at the time the forecast was made (see footnote 10 on page $11)$.

The test statistics for serial correlation (the AR tests) are calculated as the number of observations $(\mathrm{N})$ multiplied by the $\mathrm{R}^{2}$ from a regression of the residual from the forecasting equation on its lagged value(s) and the explanatory variables included in the forecasting equation.

The RESET test was calculated by adding the square of the predicted value from the forecasting equation to the vector $\mathbf{V}_{\text {t }}$, re-estimating the forecasting equation, and testing whether the square of the predicted value is significant.

The Breusch-Pagan-Godfrey test statistic for heteroscedasticity is calculated as the number of observations multiplied by the $\mathrm{R}^{2}$ from a regression of the squared residuals from the forecasting equation on the explanatory variables included in the forecasting equation.

The ARCH test statistic is $\mathrm{N}$ multiplied by the $\mathrm{R}^{2}$ from a regression of the squared residuals from the forecasting equation on a constant and the lagged squared residuals.

The significance of the structural shift dummy is a test of whether there was a shift in the constant term in the forecast equation halfway through the sample (after 1984Q3). 


\section{Table 2}

\section{Estimates of the Forward Premium Equation}

\begin{tabular}{|c|c|c|c|}
\hline & \multicolumn{3}{|c|}{ Type of Exchange Rate Forecast Assumed } \\
\hline & $\begin{array}{l}\frac{\text { General }}{\text { Forecast }} \\
\underline{\text { Model }}\end{array}$ & $\begin{array}{l}\frac{\text { Simple }}{\text { Forecast }} \\
\underline{\text { Model }}\end{array}$ & $\begin{array}{l}\underline{\text { Random }} \\
\text { Walk Forecast } \\
\underline{\text { Model }}\end{array}$ \\
\hline$\Delta\left(\mathbf{M}^{\mathrm{US}} / \mathbf{P}^{\mathrm{US}}\right)$ & $\begin{array}{l}.0056 \\
(.32)\end{array}$ & $\begin{array}{l}.0274 \\
(1.32)\end{array}$ & $\begin{array}{l}.0436 * \\
(2.05)\end{array}$ \\
\hline$\Delta\left(\mathbf{M}^{\mathrm{US}} / \mathbf{P}^{\mathrm{US}}\right)_{-1}$ & & $\begin{array}{l}.0095 \\
(.44)\end{array}$ & $\begin{array}{l}.0326 \\
(1.44)\end{array}$ \\
\hline$\Delta\left(\mathbf{M}^{\mathrm{US}} / \mathbf{P}^{\mathrm{US}}\right)_{-2}$ & & $\begin{array}{l}.0823 * \\
(4.26)\end{array}$ & $\begin{array}{l}.0451 * \\
(2.06)\end{array}$ \\
\hline$\Delta\left(\mathbf{M}^{\mathrm{J}} / \mathbf{P}^{\mathrm{J}}\right)$ & $\begin{array}{l}-.5423 * \\
(3.54)\end{array}$ & $\begin{array}{l}-.4841^{*} \\
(3.46)\end{array}$ & $\begin{array}{l}-.7506^{*} \\
(4.91)\end{array}$ \\
\hline$\Delta\left(\mathbf{M}^{\mathrm{J}} / \mathbf{P}^{\mathrm{J}}\right)_{-1}$ & & $\begin{array}{l}-.4070 * \\
(3.03)\end{array}$ & $\begin{array}{l}-.3286 * \\
(2.52)\end{array}$ \\
\hline$\Delta\left(\mathbf{M}^{\mathrm{J}} / \mathbf{P}^{\mathrm{J}}\right)_{-2}$ & & $\begin{array}{l}-.3218 * \\
(2.33)\end{array}$ & $\begin{array}{l}-.5036 * \\
(3.36)\end{array}$ \\
\hline$\Delta\left(\mathrm{A}^{\mathrm{US}} / \mathbf{P}^{\mathrm{US}}\right)$ & $\begin{array}{l}.2181 * \\
(2.09)\end{array}$ & $\begin{array}{l}.3153 * \\
(2.75)\end{array}$ & $\begin{array}{l}.3495 * \\
(3.02)\end{array}$ \\
\hline$\Delta\left(\mathrm{A}^{\mathrm{US}} / \mathrm{P}^{\mathrm{US}}\right)_{-1}$ & $\begin{array}{l}-.2108 \\
(1.80)\end{array}$ & & $\begin{array}{l}-.0504 \\
(.52)\end{array}$ \\
\hline$\Delta\left(\mathbf{A}^{\mathrm{US}} / \mathbf{P}^{\mathrm{US}}\right)_{-2}$ & $\begin{array}{l}-.0164 \\
(.18)\end{array}$ & & $\begin{array}{l}.0431 \\
(.43)\end{array}$ \\
\hline$\Delta\left(\mathbf{A}^{\mathrm{US}} / \mathbf{P}^{\mathrm{US}}\right)_{-3}$ & $\begin{array}{l}.0024 \\
(.02)\end{array}$ & & $\begin{array}{l}.2726^{*} \\
(2.71)\end{array}$ \\
\hline$\Delta\left(\mathrm{A}^{\mathrm{US}} / \mathbf{P}^{\mathrm{US}}\right)_{-4}$ & $\begin{array}{l}-.1991 * \\
(2.15)\end{array}$ & & \\
\hline
\end{tabular}




\begin{tabular}{|c|c|c|c|}
\hline$\Delta\left(\mathbf{A}^{\mathrm{J}} / \mathbf{P}^{\mathrm{J}}\right)$ & $\begin{array}{l}-.1974^{*} \\
(1.97)\end{array}$ & $\begin{array}{l}-.2444^{*} \\
(2.26)\end{array}$ & $\begin{array}{l}-.2167 * \\
(2.19)\end{array}$ \\
\hline$\Delta\left(\mathbf{A}^{\mathrm{J}} / \mathbf{P}^{\mathrm{J}}\right)_{-1}$ & $\begin{array}{l}.3194 * \\
(3.00)\end{array}$ & & \\
\hline$\Delta\left(\mathbf{B}^{\mathrm{US}} / \mathbf{P}^{\mathrm{US}}\right)$ & $\begin{array}{l}.1235^{*} \\
(2.74)\end{array}$ & $\begin{array}{l}.1439 * \\
(2.84)\end{array}$ & $\begin{array}{l}.0908 \\
(1.66)\end{array}$ \\
\hline$\Delta\left(\mathbf{B}^{\mathrm{US}} / \mathbf{P}^{\mathrm{US}}\right)_{-1}$ & $\begin{array}{l}-.0383 \\
(.84)\end{array}$ & $\begin{array}{l}-.0447 \\
(.84)\end{array}$ & \\
\hline$\Delta\left(\mathbf{B}^{\mathrm{US}} / \mathbf{P}^{\mathrm{US}}\right)_{-2}$ & $\begin{array}{l}.1929 * \\
(3.76)\end{array}$ & $\begin{array}{l}.1281 * \\
(2.58)\end{array}$ & \\
\hline$\Delta\left(\mathbf{B}^{\mathrm{J}} / \mathbf{P}^{\mathrm{J}}\right)$ & $\begin{array}{l}-.00001 \\
(.04)\end{array}$ & $\begin{array}{l}-.0010 * \\
(2.47)\end{array}$ & $\begin{array}{l}-.0012 * \\
(2.59)\end{array}$ \\
\hline$\Delta\left(\mathbf{B}^{\mathrm{J}} / \mathbf{P}^{J}\right)_{-1}$ & $\begin{array}{l}-.0001 \\
(.27)\end{array}$ & $\begin{array}{l}-.0008 * \\
(1.96)\end{array}$ & $\begin{array}{l}-.0007 \\
(1.33)\end{array}$ \\
\hline$\Delta\left(\mathbf{B}^{\mathrm{J}} / \mathbf{P}^{\mathrm{J}}\right)_{-2}$ & $\begin{array}{l}-.0014^{*} \\
(3.22)\end{array}$ & $\begin{array}{l}-.0011 * \\
(2.41)\end{array}$ & $\begin{array}{l}-.0009 \\
(1.61)\end{array}$ \\
\hline$\Delta\left(\mathbf{B}^{\mathrm{J}} / \mathbf{P}^{\mathrm{J}}\right)_{-3}$ & $\begin{array}{l}-.0011 * \\
(2.77)\end{array}$ & $\begin{array}{l}-.0018^{*} \\
(4.49)\end{array}$ & $\begin{array}{l}-.0012 * \\
(2.49)\end{array}$ \\
\hline$\Delta\left(\mathbf{B}^{\mathrm{J}} / \mathbf{P}^{J}\right)_{-4}$ & $\begin{array}{l}-.0014 * \\
(3.33)\end{array}$ & $\begin{array}{l}-.0014^{*} \\
(3.55)\end{array}$ & $\begin{array}{l}-.0021 * \\
(3.94)\end{array}$ \\
\hline $\mathbf{C A}^{\mathrm{US}} / \mathbf{P}^{\mathrm{US}}$ & $\begin{array}{l}-.0828 \\
(1.61)\end{array}$ & $\begin{array}{l}-.1382^{*} \\
(1.98)\end{array}$ & $\begin{array}{l}-.2250 * \\
(2.97)\end{array}$ \\
\hline $\mathbf{C A}^{\mathrm{J}} / \mathbf{P}^{\mathrm{J}}$ & $\begin{array}{l}-.0035^{*} \\
(3.95)\end{array}$ & $\begin{array}{l}-.0031 * \\
(2.45)\end{array}$ & $\begin{array}{l}-.0029 * \\
(2.03)\end{array}$ \\
\hline$\left(\mathrm{CA}^{\mathrm{J}} / \mathbf{P}^{\mathrm{J}}\right)_{-1}$ & & $\begin{array}{l}-.0024 \\
(1.72)\end{array}$ & $\begin{array}{l}-.0015 \\
(.91)\end{array}$ \\
\hline$\left(\mathrm{CA}^{\mathrm{J}} / \mathbf{P}^{\mathrm{J}}\right)_{-2}$ & & $\begin{array}{l}-.0011 \\
(.74)\end{array}$ & $\begin{array}{l}-.0006 \\
(.31)\end{array}$ \\
\hline$\left(\mathrm{CA}^{\mathrm{J}} / \mathbf{P}^{J}\right)_{-3}$ & & $\begin{array}{l}-.0010 \\
(.69)\end{array}$ & $\begin{array}{l}-.0028 \\
(1.53)\end{array}$ \\
\hline$\left(\mathrm{CA}^{\mathrm{J}} / \mathbf{P}^{\mathrm{J}}\right)_{-4}$ & & $\begin{array}{l}.0033 * \\
(2.89)\end{array}$ & $\begin{array}{l}.0040 * \\
(2.88)\end{array}$ \\
\hline Q1 & $\begin{array}{l}-.0084 * \\
(3.63)\end{array}$ & $\begin{array}{l}.0013 \\
(.44)\end{array}$ & $\begin{array}{l}-.0020 \\
(.66)\end{array}$ \\
\hline
\end{tabular}




\begin{tabular}{|c|c|c|c|}
\hline Q2 & $\begin{array}{l}.0035 \\
(1.79)\end{array}$ & $\begin{array}{l}-.0024 \\
(.94)\end{array}$ & $\begin{array}{l}-.00001 \\
(.004)\end{array}$ \\
\hline Q3 & $\begin{array}{l}.0074 * \\
3.87)\end{array}$ & $\begin{array}{l}-.0051^{*} \\
(2.24)\end{array}$ & $\begin{array}{l}-.0057^{*} \\
(2.14)\end{array}$ \\
\hline Constant & $\begin{array}{l}0207^{*} \\
(2.58)\end{array}$ & $\begin{array}{l}.0266^{*} \\
(3.25)\end{array}$ & $\begin{array}{l}.0155^{*} \\
(3.95)\end{array}$ \\
\hline $\mathrm{R}^{2}$ & 8178 & .8096 & .7876 \\
\hline $\mathrm{R}^{2}$ & 6964 & .6678 & .6749 \\
\hline Reset (t-statistic) & 1.00 & 1.70 & .58 \\
\hline $\operatorname{AR}(1)\left(\chi^{2}(1)\right)$ & 1.72 & .87 & .22 \\
\hline $\operatorname{AR}(4)\left(\chi^{2}(1)\right)$ & $3.94 \dagger$ & 2.73 & 1.69 \\
\hline $\operatorname{AR}(1,2,3,4)\left(\chi^{2}(4)\right)$ & $10.86 \dagger$ & 9.04 & 7.80 \\
\hline $\begin{array}{l}\text { Breusch-Pagan-Godfrey test fo } \\
\text { heteroscedasticity ( } \chi^{2} \text {-statistic) }\end{array}$ & $\begin{array}{l}35.96 \\
(29)\end{array}$ & $\begin{array}{l}31.25 \\
(30)\end{array}$ & $\begin{array}{l}33.08 \\
(26)\end{array}$ \\
\hline $\begin{array}{l}\text { ARCH heteroscedasticity test } \\
\left(\chi^{2}(1) \text {-statistic }\right)\end{array}$ & .18 & 1.94 & 1.42 \\
\hline $\begin{array}{l}\text { Structural shift dummy } \\
\text { (t-statistic) }\end{array}$ & .002 & 1.66 & .63 \\
\hline $\begin{array}{l}\text { Test of exclusion restrictions } \\
\text { imposed by the lag length } \\
\text { reduction procedure }\left(\chi^{2} \text {-statisti }\right.\end{array}$ & $\begin{array}{l}25.76 \\
(21)\end{array}$ & $\begin{array}{l}14.51 \\
(18)\end{array}$ & $\begin{array}{l}15.12 \\
(17)\end{array}$ \\
\hline $\begin{array}{l}\text { Test of the normality of the } \\
\text { residuals }\left(\chi^{2} \text {-statistic) }\right.\end{array}$ & $\begin{array}{l}11.51 \\
(4)\end{array}$ & $\begin{array}{l}15.12 \ddagger \\
(4)\end{array}$ & $\begin{array}{l}6.15 \\
(2)\end{array}$ \\
\hline
\end{tabular}

Notes:

The estimated parameters in this table correspond to the vector of parameters $\gamma$ in equation (8) when the rational expectations cross-equation restrictions (equation (9)) are imposed.

$\mathrm{R}^{2}=$ One minus the ratio of the sum of squared residuals from the forward premium equation divided by the total sum of squares from this equation. $\mathrm{R}^{2}$ is calculated in the same fashion as $\mathrm{R}^{2}$ except that the ratio that is subtracted from one is multiplied by $(\mathrm{N}-1) /(\mathrm{N}-\mathrm{k})$ where $\mathrm{N}$ is the number of observations and $\mathrm{k}$ is the number of parameters in the forward premium equation.

$\dagger$ Indicates that the hypothesis of no serial correlation is rejected at the 5 percent significance level, but not at the 1 percent level. 
Indicates that the hypothesis of normality of the residuals is rejected at a 1 percent significance level. The normality test uses a multivariate extension, described in Richardson and Smith (1993), of the Jarque-Bera (1987) normality test.

See also notes to Table 1. 


\section{Table 3}

\section{Tests of the Rational Expectations and No Risk Premium Hypotheses}

Type of Exchange Rate Forecast Assumed

\section{Hypothesis}

$\begin{array}{lll}\text { General } & \underline{\text { Simple }} & \underline{\text { Random }} \\ \underline{\text { Forecast }} & \underline{\text { Forecast }} & \underline{\text { Forecast }}\end{array}$

1. Rational Expectations $(\mathbf{b}=\boldsymbol{\beta})$

$50.72 \dagger$

7.19

2. No Risk Premium

A. Rational Expectations Imposed

(i) No time-varying risk premium $(\boldsymbol{\gamma}=0 \mid \mathbf{b}=\boldsymbol{\beta})$

$70.60 \dagger$

(ii) No constant or time-varying risk premium $(\boldsymbol{\gamma}=0$ and $\alpha=0 \mid \mathbf{b}=\boldsymbol{\beta})$
$71.72 \dagger$

(23)
$118.32 \dagger$

(25)

$119.45 \dagger$

B. Rational Expectations Not Imposed

(i) No time-varying risk premium $(\gamma=0)$

(ii) No constant or time-varying risk premium $(\gamma=0$ and $\alpha=0)$
$69.30 \dagger$

$74.42 \dagger$

(23)
$117.52 \dagger$

$151.21 \dagger$

(26)
$117.80 \dagger$

(26)

$155.80 \dagger$

(27)

Notes:

$\dagger$ The hypothesis is rejected at the 95 percent confidence level.

These likelihood ratio test statistics have a $\chi^{2}$ distribution with the number of degress of freedom given in brackets.

The three quarterly dummy variables are assumed to contribute to the time-varying component of the risk premium. That is, their parameters are elements of the vector $\gamma$. 


\section{Table 4}

\section{Correlation of the Forward Premium with the Predicted Risk Premium and the Forecast Exchange Rate Change}

Type of Exchange Rate Forecast Assumed

\begin{tabular}{lll}
\hline General & $\underline{\text { Simple }}$ & $\underline{\text { Random Walk }}$ \\
$\underline{\text { Forecast }}$ & $\underline{\text { Forecast }}$ & $\underline{\text { Forecast }}$
\end{tabular}

$\underline{\text { Risk Premium }}$

.782

.859

.887

Forecast Exchange

$-.280$

$-.069$

0

$\underline{\text { Rate Change }}^{\mathrm{b}}$

Notes:

${ }^{\text {a }}$ The risk premium is obtained using the coefficient estimates from Table 2.

${ }^{\mathrm{b}}$ The forecast exchange rate change is obtained using the coefficient estimates from Table 1. 


\section{Appendix I: Derivation of the Risk Premium Equation}

Following the model of Glassman and Riddick (1996), the model of international portfolio selection presented here takes a very general form that allows for deviations from purchasing power parity and for differences in asset preferences across countries. Investors choose optimal portfolio shares to maximize expected utility, where the latter is a function of the mean and variance of end-of-period real wealth. ${ }^{22}$ For a representative investor, this maximization problem takes the form:

$$
\operatorname{Max} \mathrm{E}(\mathrm{U})=\mathbf{x}_{\mathrm{n}}^{\prime} \mathrm{E}\left(\mathbf{R}_{\mathrm{n}}\right)-1 / 2 \delta\left(\mathbf{x}_{\mathrm{n}}^{\prime} \mathbf{\Omega}_{\mathrm{n}} \mathbf{x}_{\mathrm{n}}\right),
$$

where there are $\mathrm{n}$ assets (one for each country), $\mathbf{x}_{\mathrm{n}}$ is an $\mathrm{n} \times 1$ vector of portfolio shares; $\mathrm{E}\left(\mathbf{R}_{\mathrm{n}}\right)$ is an $\mathrm{n} \times 1$ vector of expected real asset returns; $\delta$ is the coefficient of relative risk aversion (assumed to be the same for all investors); $\boldsymbol{\Omega}_{\mathrm{n}}$ is the $\mathrm{n} \times \mathrm{n}$ covariance matrix of real asset returns; and $\mathbf{l}_{\mathrm{n}}^{\prime} \mathbf{x}_{\mathrm{n}}=1$, where $\mathbf{t}_{\mathrm{n}}$ is an $\mathrm{n} \times 1$ vector of ones. Following Glassman and Riddick (1996), assume that the purchasing power index (the inverse of the price index) for investors has a Cobb-Douglas form and that the nominal local currency price of each asset, each exchange rate and the purchasing power index follow geometric Brownian motion. The solution to this optimization problem yields $\mathbf{x}$, the $(n-1) \times 1$ vector of the optimal portfolio shares of the first $n-1$ assets:

$$
\mathbf{x}=(1 / \delta) \boldsymbol{\Sigma}^{-1}\left(\mathrm{E}(\mathbf{r})-\mathbf{r r}^{\mathrm{n}}\right)+(1-(1 / \delta)) \boldsymbol{\Sigma}^{-1} \mathbf{\Phi} \mathbf{a}
$$

where $E(\mathbf{r})$ is the vector of expected nominal asset returns (measured in the $\mathrm{n}^{\text {th }}$ currency); $\mathrm{r}^{\mathrm{n}}$ is the nominal rate of return on the (riskfree) $\mathrm{n}^{\text {th }}$ asset; $\boldsymbol{\Sigma}$ is the (n-1) $\times(\mathrm{n}-1)$ covariance matrix of the nominal returns on the first $\mathrm{n}-1$ assets; $\boldsymbol{\Phi}$ is the $(\mathrm{n}-1) \times(\mathrm{n}-1)$ matrix of the covariances between nominal asset returns and national inflation rates; $\mathbf{a}$ is a vector of the investor's consumption expenditure shares on goods from the first $\mathrm{n}-1$ countries; and the vectors and matrices without a subscript are of order (n-1).

Aggregating asset demands across all countries and equating aggregate asset demands and aggregate asset supplies yields:

$$
\mathrm{E}(\mathbf{r})-\mathbf{t r}^{\mathrm{n}}=\delta \boldsymbol{\Sigma} \mathbf{X W} / \mathbf{\iota}^{\prime} \mathbf{W}+(1-\delta) \boldsymbol{\Phi} \mathbf{A W} / \mathbf{\iota}^{\prime} \mathbf{W},
$$

where $\mathbf{X}=\left[\mathbf{x}^{1}, \mathbf{x}^{2}, \ldots, \mathbf{x}^{\mathrm{n}-1}\right]$ is the matrix of individual country optimal portfolio shares and $\mathbf{x}^{\mathrm{j}}$ is the vector of optimal portfolio shares for investors from country $\mathbf{j} ; \mathbf{W}$ is an $(n-1) \times 1$ vector of national wealth levels; $\mathbf{t}$ is an $(\mathrm{n}-1) \times 1$ vector of ones; $\mathbf{\imath}^{\prime} \mathbf{W}$ equals world wealth; and $\mathbf{A}=\left[\mathbf{a}^{1}, \mathbf{a}^{2}, \ldots, \mathbf{a}^{\mathrm{n}-1}\right]$ is a matrix of individual country consumption expenditure shares.

\footnotetext{
${ }^{22}$ The Solnik (1974) model assumes investors have a one-period investment horizon. Extending the model to allow for intertemporal effects is quite difficult. Engel (1994) notes that simulation exercises in an unpublished paper by Restoy suggest that these intertemporal effects may not be large. Solnik's model is also partial equilibrium in that he assumes that the exchange rate and interest rate processes are determined exogenously. However, a complete markets model which endogenizes equilibrium asset pricing, of the type presented in Lucas (1982), necessarily makes many simplifying assumptions (such as identical consumption preferences of investors across countries) which, as Lewis (1995) notes, makes this type of model less useful in explaining the empirical behaviour of the foreign exchange market.
} 
Let the assets of countries 1 and 2 be the bonds of the "domestic" and "foreign" country. These have expected returns in the $\mathrm{n}^{\text {th }}$ currency $\mathrm{E}\left(\mathrm{r}^{\mathrm{d}}\right)$ and $\mathrm{E}\left(\mathrm{r}^{\mathrm{f}}\right)$, respectively, where $\mathrm{n} \neq 1,2$. Then:

$$
\mathrm{E}\left(\mathrm{r}_{\mathrm{t}}^{\mathrm{d}}\right)-\mathrm{E}\left(\mathrm{r}_{\mathrm{t}}^{\mathrm{f}}\right)=\mathrm{i}_{\mathrm{t}}^{\mathrm{d}}-\mathrm{i}_{\mathrm{t}}^{\mathrm{f}}-\Delta \mathrm{s}_{\mathrm{t}+1}^{\mathrm{e}},
$$

where $\mathrm{i}^{\mathrm{d}}$ and $\mathrm{i}^{\mathrm{f}}$ are the expected nominal return in local currency for the domestic and foreign (country 1 and 2) bonds, respectively, and $\mathrm{s}$ is the $\log$ of the domestic currency price of the foreign currency, and $\Delta \mathrm{s}_{\mathrm{t}+1}^{\mathrm{e}}=\mathrm{E}_{\mathrm{t}}\left(\mathrm{s}_{\mathrm{t}+1}\right)-\mathrm{s}_{\mathrm{t}}$ is the one period ahead expected rate of change of the domestic currency price of the foreign currency.

Define the risk premium, $\rho$, as follows:

$$
\rho_{\mathrm{t}} \equiv \mathrm{i}_{\mathrm{t}}^{\mathrm{d}}-\mathrm{i}_{\mathrm{t}}^{\mathrm{f}}-\Delta \mathrm{s}_{\mathrm{t}+1}^{\mathrm{e}} \text {. }
$$

Using the first two rows of expression (A3) to substitute for $\mathrm{E}\left(\mathrm{r}^{\mathrm{d}}\right)$ and $\mathrm{E}\left(\mathrm{r}^{\mathrm{f}}\right)$ in equation (A4) yields an equation which, when combined with equation (A5), yields the following expression for the risk premium:

$$
\rho_{\mathrm{t}}=\delta \sum_{\mathrm{i}=1}^{\mathrm{n}-1}\left(\sigma_{\mathrm{di}}-\sigma_{\mathrm{fi}}\right) \mathrm{x}_{\mathrm{it}}^{\mathrm{m}}+(1-\delta) \sum_{\mathrm{h}=1}^{\mathrm{n}-1} \sum_{\mathrm{k}=1}^{\mathrm{n}-1}\left(\varphi_{\mathrm{dh}}-\varphi_{\mathrm{fh}}\right) \mathrm{a}_{\mathrm{h}}^{\mathrm{k}} \mathrm{w}_{\mathrm{t}}^{\mathrm{k}} \overline{\mathrm{W}}_{\mathrm{t}}^{-1}
$$

where

$$
x_{i t}^{m}=\sum_{j=1}^{n-1} x_{i t}^{j} w_{t}^{j} \bar{w}_{t}^{-1}
$$

where $\mathrm{x}_{\mathrm{i}}^{\mathrm{m}}$ is an element of the vector $\mathbf{x}^{\mathrm{m}}=\left(\mathbf{X W} / \mathbf{\imath}^{\prime} \mathbf{W}\right)$ that, in equilibrium, is equal to the world market portfolio; the parameters $\sigma_{\mathrm{di}}$ and $\sigma_{\mathrm{fi}}$ are elements of the matrix $\boldsymbol{\Sigma}$ and represent the covariances of the nominal returns on domestic and foreign bonds with the return on asset $i$, respectively; $x_{i}^{j}$ is the portfolio share held in asset $i$ of the representative investor from country $j$; $\varphi_{\mathrm{dh}}$ and $\varphi_{\mathrm{fh}}$ are elements of the matrix $\boldsymbol{\Phi}$ that represent the covariances of returns on domestic and foreign bonds with the inflation rate in country $\mathrm{h}$, respectively; and $\mathrm{a}_{\mathrm{h}}^{\mathrm{k}}$ represents country $\mathrm{k}$ investors' consumption expenditure share on goods from country $h$.

As can be seen from equation (A6), the forward exchange rate risk premium, $\rho$, varies with the world market portfolio $\left(\mathbf{x}^{\mathrm{m}}\right)$, with individual country wealth levels $\left(\mathrm{W}^{\mathrm{j}}\right)$ and with total world wealth, W. Assuming all covariance terms and expenditure shares are constant, and so are suppressed, the risk premium can be expressed as:

$$
\rho_{\mathrm{t}}=\rho\left(\mathbf{x}_{\mathrm{t}}^{\mathrm{m}}, \mathbf{W}_{\mathrm{t}}, \mathrm{W}_{\mathrm{t}}\right) .
$$




\section{Appendix II: Variable Definitions and Data Sources}

Unless indicated otherwise, the data was obtained from the International Monetary Fund's International Financial Statistics (IFS) CD-ROM.

$\mathbf{A}^{\mathbf{J}}$ - Japan equity values, proxied by an index of the average of daily closing prices for all shares listed on the Tokyo exchange.

$\mathbf{A}^{\text {US }}$ - U.S. equity values, proxied by an index of U.S. industrial share prices produced as a Laspeyres-type index by the Standard and Poors Corporation for 400 industrials on the New York Exchange, based on daily closing quotations.

$\mathbf{B}^{\mathbf{J}}$ - Japan government bonds, measured as public issues: Total net central government. Obtained from the OECD Financial Statistics Monthly, Table A.163/21 Security Issues until 1978, and Table D/21 Security Issues after 1978.

$\mathbf{B}^{\text {US }}$ - U.S. government bonds, measured as public issues: Total net central government. Obtained from the OECD Financial Statistics Monthly, Table I.C.3/07 Security Issues until 1978 and Table D/07 Security Issues from 1978. Due to a break in continuity of the data from the first quarter of 1974, collection of the data series commenced in that quarter.

$\mathbf{C A}^{\mathbf{J}}$ - Japan current account, defined as the trade balance plus the balance on services, income, private unrequited transfers, and official unrequited transfers not included elsewhere. Data covering 1974-1976 is not available on the IFS CD-ROM, and it has been taken directly from the hard copies of the IFS (series 70a, and 77a.d).

$\mathbf{C A}^{\text {US }}$ - U.S. current account, defined as the trade balance plus the balance on services, income, private unrequited transfers, and official unrequited transfers not included elsewhere.

f - The log of the three-month forward yen price of one U.S. dollar. End of period.

$\mathbf{M}^{\mathbf{J}}$ - Japan money supply measured as M2. Constructed as the sum of M1 plus quasi-money.

$\mathbf{M}^{\text {US }}$ - The U.S. money supply measured as M2. Constructed as the sum of M1 and quasi-money.

$\mathbf{P}^{\mathbf{J}}$ - Japan consumer price index.

$\mathbf{P}^{\mathrm{US}}$ - U.S. consumer price index.

$\mathbf{r s}^{\mathbf{J}}$ - Japan money market rate.

$\mathbf{r s}^{\text {US }}$ - U.S. 3-month commercial paper rate, for commercial paper placed for firms whose bond rating is AA or equivalent. Average of daily rates.

$\mathbf{r l}^{\mathrm{US}}$ - U.S. long term interest rate, measured as U.S. government 10 year bond yield (constant maturity).

$\mathbf{r l}^{\mathbf{J}}$ - Japan long term interest rate, measured as the arithmetic yield to maturity of all government bonds with seven years to maturity. Monthly series are compiled from end-of-month 
prices quoted on the Tokyo stock exchange.

s - The log of the Japanese yen price of one U.S. dollar. The end of period midpoint rate in the interbank foreign exchange market in Tokyo.

$\mathbf{Y}^{\mathrm{US}}$ - U.S. gross domestic product.

$\mathbf{Y}^{\mathrm{J}}$ - Japan gross domestic product. 


\section{Appendix III: Specification of the Estimating Equations}

\section{A: The Forecasting Equation}

The current value and four lags of each of the variables mentioned in Section 4.2 as possible contributors to a forecast of the exchange rate were added individually to an equation with $\mathrm{s}_{\mathrm{t}+1}-\mathrm{s}_{\mathrm{t}}$ as the dependent variable and the current and four lagged differences of the exchange rate, a trend (included to ensure that the initial specification is as general as possible) and three seasonal dummy variables as independent variables. For each variable, the number of lags was reduced by sequentially eliminating the variable with the smallest t-statistic until all the included variables were significant using a 20 percent confidence interval. (The lagged values of the change in the exchange rate, the trend and seasonal dummy variables were not eliminated at this stage.)

All the variables which were found to be significant in the initial stage described above were then included in a forecasting equation along with the current and four lagged differences of the exchange rate, a trend and three seasonal dummy variables. To reduce the number of variables in this forecasting equation (so as to improve its efficiency and forecast accuracy), variables were eliminated sequentially starting with the variable associated with the smallest t-statistic. This sequential reduction procedure was terminated when all the remaining variables were significant using a 95 percent confidence interval. Once the sequential reduction procedure had been completed, all the variables which had been eliminated at any stage in the procedure were added back individually into the final equation and tested for significance. If any were significant (a small number were), the sequential reduction procedure was started again with these variables included in the forecasting equation. The final form of the forecasting equation was determined when none of the excluded variables were significant when added individually back into the forecasting equation. The final version of the forecasting equation is presented in Table 1.

\section{Table A1: One-Quarter Ahead Exchange Rate Forecast Comparisons}

\section{Case 1: Ten Year Forecast}

General

Forecast

$\underline{\text { Model }}$

Case 2: Five Year Forecast

\begin{tabular}{lllr} 
& $\begin{array}{l}\text { General } \\
\text { Forecast } \\
\text { Model }\end{array}$ & $\underline{\text { Random Walk }}$ & \multicolumn{2}{c}{ Random Walk with Drift } \\
MAE & $.0463(.0441)$ & .0551 & $.0539(.0536)$ \\
RMSE & $.0553(.0528)$ & .0659 & $.0642(.0638)$
\end{tabular}

Estimation Period: 1975Q2 - 1984Q1

Forecast Period: 1984Q2 - 1994Q1

Estimation Period: 1975Q2 - 1989Q1

Forecast Period: 1989Q2 - 1994Q1

General

Forecast

$\underline{\text { Model }}$

MAE

$.0385(.0382)$

.0525

$.0474(.0476)$ 
Notes: $\mathrm{MAE}=$ mean absolute error.

$\mathrm{RMSE}=$ root mean squared error.

Note: The figures in brackets are for a rolling regression in which the model was estimated using data up to the period just prior to that being forecast. 
The following methodology was used to determine the most parsimonious specification for all three versions of the forward premium equation (the versions associated with the general and simple forecast models as well as the random walk forecast). Each equation was initially estimated with the current value and four lags of the U.S. and Japanese real change in M2, real change in the stock index, real change in government bonds, and the real current account balance as well as a constant and three seasonal dummy variables. Joint nonlinear estimation of equations (7) and (8) was employed for the cases that use the general and simple forecast models. In order to increase the efficiency of the estimates, the lag lengths of the explanatory variables were reduced in each case by eliminating the longest lag that was insignificant using a 95 percent confidence interval and then re-estimating the model. This lag reduction procedure was terminated when the longest lag associated with each variable was significant at 95 percent. The variables that were excluded during the lag reduction procedure were then added back into the forward premium equation individually. Those that were individually significant (almost none) were then added back as a group and the reduction procedure repeated. This process was repeated until none of the excluded variables were individually significant when added back, one by one, into the forward premium equation. The current value of each variable was retained in the model even if not statistically significant at a 5 percent significance level. A joint test of all the exclusion restrictions implied by the lag reduction procedure could not reject these restrictions. 


\section{References}

Ayuso, Juan and Fernando Restoy (1996) "Interest rate parity and foreign exchange risk premia in the ERM," Journal of International Money and Finance 15:3, 369-382.

Baillie, Richard T. and Tim Bollerslev (1990) "A multivariate generalized ARCH approach to modeling risk premia in forward foreign exchange rate markets," Jounal of International Money and Finance, 9, 309-324.

Baillie, Richard T. and William P. Osterberg (1997) "Central bank intervention and risk in the forward market," Journal of International Economics, 43, 483-497.

Bekaert, Geert and Robert J. Hodrick (1992) "Characterizing predictable components in excess returns on equity and foreign exchange markets" Journal of Finance, 47(2), 467-509.

Bekaert, Geert and Robert J. Hodrick (1993) "On biases in the measurement of foreign exchange risk premiums," Journal of International Money and Finance, 12, 115-138.

Bilson, John F.O. (1979) "Recent developments in monetary models of exchange rate determination," IMF Staff Papers 26:2, 201-23.

Bilson, John F. O.(1981) "The `Speculative efficiency' hypothesis," Journal of Business 54:3, 435451.

Black, Stanley W. and Michael K. Salemi (1988) "FIML estimation of the dollar-deutschemark risk premium in a portfolio model," Journal of International Economics, 25, 205-224.

Boothe, Paul and David Longworth (1986) "Foreign exchange market efficiency tests: Implications of recent findings," Journal of International Money and Finance 5, 135-152.

Breuer, Janice Boucher and Mark E. Wohar (1996) "The Road less travelled: institutional aspects of data and their influence on empirical estimates with an application to tests of forward rate unbiasedness," Economic Journal, 106, 26-58.

Canova, Fabio and Takatishi Ito (1991) "The Time-series properties of the risk premium in the yen/dollar exchange market," Journal of Applied Econometrics, 6, 125-142.

Cavaglia, Stefano M.F.G, Willem F.C. Verschoor and Christian C. P. Wolff (1994) "On the biasedness of forward foreign exchange rates: irrationality or risk premia?" Journal of Business, 67:3, 321-343.

Chinn, Menzie D. and Richard A. Meese (1995) "Banking on currency forecasts: How predictable is change in money?" Journal of International Economics, 38, 161-178.

Dominguez, Kathryn M. and Jeffrey A. Frankel (1993) "Does foreign-exchange intervention matter? The portfolio effect" American Economic Review, 83:5, 1356-1369.

Dornbusch, Rudiger (1976) "Expectations and exchange rate dynamics," Journal of Political Economy, 84, 1161-1176. 
Driskill, Robert A. (1981) "Exchange rate dynamics: An empirical investigation," Journal of Political Economy 89:2, 357-371.

Eichenbaum, Martin and Charles L. Evans (1995) "Some empirical evidence on the effects of shocks to monetary policy on exchange rates," Quarterly Journal of Economics, 975-1009.

Engel, Charles (1994) "Tests of CAPM on an international portfolio of bonds and stocks," in Jeffrey A. Frankel, ed., The Internationalization of Equity Markets, University of Chicago Press, 149172.

Engel, Charles (1995) "Why is the forward exchange rate forecast biased? A survey of recent evidence," University of Washington Discussion Paper No. 95-08.

Engel, Charles and James D. Hamilton (1990) "Long swings in the dollar: Are they in the data and do markets know it?" American Economic Review, 80, 689-713.

Engel, Charles and Anthony P. Rodrigues (1989) "Tests of international CAPM with time-variying covariances," Journal of Applied Econometrics, 4, 119-138.

Fama, Eugene F. (1984) "Forward and spot exchange rates" Journal of Monetary Economics 34 319338.

Flood, Robert P., Peter M. Garber, and Charles Kramer (1996) "Collapsing exchange rate regimes: Another linear example," Journal of International Economics 41, 223-234.

Frankel, Jeffrey A. (1979) "On the mark: A Theory of floating exchange rates based on real interest differentials," American Economic Review, 69:4, 610-22.

Frankel, Jeffrey A. (1982) "In search of the exchange risk premium: A Six-currency test assuming mean-variance optimization" Journal of International Money and Finance 1 255-274.

Frankel, Jeffrey A. and Menzie D. Chinn (1993) "Exchange rate expectations and the risk premium: Tests for a cross section of 17 currencies," Review of International Economics 1, 136-44.

Frankel, Jeffrey A. and Andrew K. Rose (1995) "Empirical research on nominal exchange rates" Handbook of International Economics, vol. III, in G. Grossman and K. Rogoff, Editors, Elsevier Science, 1689-1729.

Froot, Kenneth A. and Jeffrey A. Frankel (1989) "Forward discount bias: Is it an exchange risk premium?" Quarterly Journal of Economics, 139-161.

Froot, Kenneth A. and Richard H. Thaler (1990) "Anomalies: Foreign exchange," Journal of Economic Perspectives, 4:3, 179-192.

Giorgianni, Lorenzo (1997) "Foreign exchange risk premium: does fiscal policy matter? Evidence from Italian data" IMF Working Paper WP/97/39.

Goldberg, Linda S. (1994) "Predicting exchange rate crises," Journal of International Economics 36, 413-30. 
Glassman, Debra A. and Leigh A. Riddick (1996) "Why empirical international portfolio models fail: evidence that model misspecification creates home asset bias," Journal of International Money and Finance, 15:2 275-312.

Hai, Weike, Nelson C. Mark and Yangru Wu (1997) "Understanding spot and forward exchange rate regressions," Journal of Applied Econometrics, 12, 715-734.

Hodrick, Robert J. (1989) "Risk, uncertainty, and exchange rates," Journal of Monetary Economics, 23 433-459.

$\mathrm{Hu}$, Xiaoqiang (1997) "Macroeconomic uncertainty and the risk premium in the foreign exchange market," Journal of International Money and Finance, 16:5, 699-718.

Jarque, C. M. and A. K. Bera (1987) "A Test for normality of observations and regression residuals," International Statistical Review, 55, 163-72.

Krugman, Paul (1991) "Target zones and exchange rate dynamics" Quarterly Journal of Economics $106: 3,311-25$.

Leiderman, Leonardo (1980) "Macroeconometric testing of the rational expectations and structural neutrality hypotheses for the United States" Journal of Monetary Economics, 6, 69-82. 
Lewis, Karen K. (1988) "Testing the portfolio balance model: a Multi-lateral approach," Journal of International Economics, 24, 109-127.

Lewis, Karen K. (1995) "Puzzles in international financial markets" Handbook of International Economics, Vol.III, in G. Grossman and K. Rogoff, Editors, 1913-1971.

Liu, Peter C. and G.S. Maddala (1992) "Rationality of survey data and tests for market efficiency in the foreign exchange markets," Journal of International Money and Finance, 11, 366-381.

Longworth, David (1981) "Testing the efficiency of the Canadian-U.S. exchange market under the assumption of no-risk premium," Journal of Finance 36, 43-49.

Lucas, Robert E. (1982) "Interest rates and currency prices in a two-country world," Journal of Monetary Economics 10, 335-359.

Lui, Yu-Hon and David Mole (1998) "The use of fundamental and technical analyses by foreign exchange dealers: Hong Kong evidence," Journal of International Money and Finance, 17, 535-545.

Mark, Nelson C. (1995) "Exchange rates and fundamentals: Evidence on long-horizon predictability," American Economic Review, 85:1, 201-218.

MacDonald, R. and M. P. Taylor (1992) "Exchange rate economics: A survey," IMF Staff Papers, $39: 1,1-57$.

MacDonald, Ronald and Thomas S. Torrance (1990) "Expectations formation and risk in four foreign exchange markets," Oxford Economic Papers, 42, 544-561.

Meese, Richard A. (1986) "Testing for bubbles in exchange markets: A case of sparkling rates?" Journal of Political Economy, 94:2, 345-373.

Meese, Richard A. and Kenneth Rogoff (1983) "Empirical exchange rate models of the seventies: Do they fit out of sample?" Journal of International Economics 14 3-24.

Mishkin, Frederic S. (1983) A Rational Expectations Approach to Macroeconometrics. Chicago: University of Chicago Press.

Nessén, Marianne (1997) "Exchange rate expectations, the forward exchange rate bias and risk premia in target zones," Open Economies Review, 8:2 99-136.

Nieuwland, Frederick G.M.C, Willem F.C. Verschoor and Christian C.P. Wolff (1998) "EMS exchange rate expectations and time-varying risk premia," Economics Letters 60 351-355.

Obtsfeld, Maurice and Kenneth Rogoff (1984) "Exchange rate dynamics with sluggish prices under alternative price-adjustment rules" International Economic Review 25:1, 159-174.

Papell, David H. (1989) "Monetary policy in the United States under flexible exchange rates," American Economic Review 79:5, 1106-1116. 
Richardson, M. and T. Smith (1993) "A Test for multivariate normality in stock returns," Journal of Business, 66, 295-321.

Solnik, Bruno H. (1974) "An equilibrium model of the international capital market," Journal of Economic Theory 8, 500-524.

Svensson, Lars E. O. (1992) "An Interpretation of recent research on exchange rate target zones," Journal of Economic Perspectives, 6:4, 119-144. 
Takagi, Shinji (1991) "Exchange rate expectations: A survey of survey studies" International Monetary Fund Staff Papers, 38(1), 156-183.

Taylor, Mark P. (1995) "The economics of exchange rates" Journal of Economic Literature XXXIII $13-47$.

Taylor, Mark P. and Helen Allen (1992) "The use of technical analysis in the foreign exchange market," Journal of International Money and Finance, 11, 304-314.

Thomas, S.H. and M.R. Wickens (1993) "An international CAPM for bonds and equities," Journal of International Money and Finance, 12, 390-412. 